\title{
The Use of UAV Photogrammetric Technology in Order to Make the Cadastral Documentation of Detachment in Two Lots of a Property Located in Valea Ierii, Cluj County
}

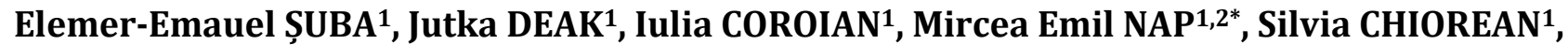 \\ Ioan LUPUȚ ${ }^{1}$, Diana FICIOR ${ }^{1}$
}

${ }^{1}$ Department of Land Measurements and Exact Sciences, Faculty of Horticulture, University of Agricultural Sciences and Veterinary Medicine Cluj-Napoca, 3-5 Mănăștur St., 400372, Cluj-Napoca, Romania

2 Department of Topography and Cadastre, Faculty of Geodesy, Technical University of Civil Engineering Bucharest, 122-124 Lacul Tei Blvd., 2nd District, 020396, Bucharest, Romania

*Corresponding author: Mircea Emil NAP e-mail: mircea.nap@usamvcluj.ro

RESEARCH ARTICLE

\begin{abstract}
The cadastre and the land book form a unitary and mandatory system that ensures technical, economic and legal records of all the properties on the territory of the country. This paper includes the presentation of the operations necessary to prepare the cadastral documentation for detachment in two lots, using UAV photogrammetric technology. The studied area is located in the suburbs of Valea Ierii locality, with an area of $212353 \mathrm{sqm}$. The main part of the project was based on the use of the UAV photogrammetric method to survey the area. At the same time, two GNSS receivers were used to complete the photogrammetric measurements. Control and verification points were premarked on the ground, the coordinates of which were determined by the real-time kinematic GNSS method. This operation was followed by performing the photogrammetric flight using an UAS platform. The flight lasted about 17 minutes, covered an area of 29 ha and 288 frames were captured. The front overlap between photos was set to $75 \%$ and the side overlap to $65 \%$. New technologies for taking frames and processing them have been adopted, through methods that involve a low cost and a shorter time to perform specific operations.
\end{abstract}

Keywords: cadastral documentation; ortophotomap; UAV.

Received: 1 November 2020

Accepted: 11 May 2021

Published: 14 May 2021

DOI:

15835/buasvmcn-hort:2020.0071
2021 Authors. The papers published in this journal are licensed under the Creative Commons Attribution-NonCommercialNoDerivatives 4.0 International License

\section{INTRODUCTION}

The aim of the project is to create a cadastral documentation for the detachment in two lots of a building located outside the Valea Ierii commune in Cluj county. The detachment of this building aims at the tourist development of the area, by concession or rental of the second lot, as the building is located in the immediate vicinity of the ski resort Buscat.

According to P.U.Z. "Composesoratul Muntele Băișorii", the targeted area is proposed to be used for the purpose of tourist and leisure facilities, and will be built with an average height, hotels and guesthouses with a maximum capacity of 20 seats or holiday homes.

The cadastre and the land book form a unitary and obligatory system that ensures technical, economic and legal records of all the buildings on the territory of the country (Ficior et al., 2011; Păunescu et al., 2016; Păunescu et al., 2017). Through the cadastre, operations are performed that include the identification, description, measurement and registration of real estate in the documents specific to the cadastre: at the same time, the real estate is represented on maps and cadastral plans. The functions of the cadastre include the technical, economic and legal branch. 
The technical function of the cadastre aims to determine the position, configuration and size of land areas and buildings. These data are obtained through operations specific to the fields of geodesy, topography, photogrammetry and cartography (Herbei et al., 2016; Moscovici et al., 2016; Ortelecan et al., 2016).

The economic function aims to establish the taxable value of real estate, taxes and duties.

The legal function of the cadastre aims at identifying the owners of the buildings and their registration in the land book. There is also other information about real estate, such as their description, rights or legal relationships related to them.

Detachment is the operation by which a building that is registered in the land register is divided into two or more buildings that may have equal or unequal areas. These will be recorded in separate land books. The condition that all buildings resulting from the detachment have access to a road or, as the case may be, that the easement condition has been met must be respected.

\section{MATERIALS AND METHODS}

The measurements were performed using a total Leica FlexLine TS03 station, two Trimble R8s GPS receivers with an external radio and a DJI Phantom 4 Pro drone. Specific methods for determining horizontal and vertical angles were used to perform the measurements. GPS measurements were performed using the fast static method and the real-time kinematic method (Bădescu et al., 2011; Coșarcă, 2003; Dragomir et al., 2015; Neuner, 2000). Photogrammetric survey was performed by the UAV photogrammetric method.

A series of specialized software were used to process the elements obtained from the measurements, such as: DroneDeploy, Agisoft Photoscan, Global Mapper and AutoCAD.

Before performing the actual photogrammetric flight, it is necessary to make a flight plan. It involves going through some stages. (Sestraș et al., 2018; Sălăgean et al., 2018). In this case, the flight plan was made through the DroneDeploy application. In the first phase we selected on the map the area to be covered, and the flight height. Then the front and side overlays of the frames were set and the automatic obstacle avoidance mode was activated, in order to avoid accidents or unforeseen situations. Depending on the selected parameters, the area on which the flight is to be performed was calculated, the flight strips were created, the time and the number of images to be taken during the flight were estimated (Carvajal et al., 2011; Ionescu, 2004; Popescu, 2010; Toderaș, 2007; Vorovencii, 2010).

Photogrammetric pre-marking: after marking the points it is necessary to determine the coordinates. The coordinates were determined with GPS devices by the real-time kinematic method (RTK) (Călin et al., 2015, Păunescu et al., 2012; Sestraș et al., 2019). Thus, 11 points were marked on the ground, which were used for processing and compensating the data obtained from the photogrammetric flight. The photogrammetric flight was performed automatically via the same application. When all conditions were validated, the drone was able to take off.

The DroneDeploy application allows real-time viewing of the image recorded by the camera, the location of the drone, how far it is from the base, the speed at which it moves, the number of images taken and the percentage remaining in the battery. There is also the possibility to bring the drone to the ground before the end of the flight (Sălăgean et al., 2019a; Sălăgean et al., 2019b; Șuba et al., 2019).

After taking over the data from the field, it is necessary to carry out their processing in order to obtain the digital orthophotoplan (Șuba et al., 2017a; Șuba et al., 2017b). Data processing was performed in Agisoft Photoscan software.

\section{RESULTS AND DISCUSSIONS}

The photogrammetric flight was performed under normal conditions (Figure 1), had a duration of $16 \mathrm{~min} 29 \mathrm{sec}$, an area of 29 ha was covered and 288 frames were taken. A frontal overlap was established of $75 \%$ and lateral overlap of $65 \%$. The drone was launched from the point with the highest elevation on the studied area.

The following steps were taken to obtain the digital orthophotoplan:

- project creation;

- importing raw images;

- collecting landmarks;

- refining or adjusting landmarks;

- block aerotriangulation compensation;

- determining the accuracy of aerotriangulation;

- generating and choosing the digital terrain model (DTM);

- obtaining the orthorectification images, respectively the digital orthophotoplan. 


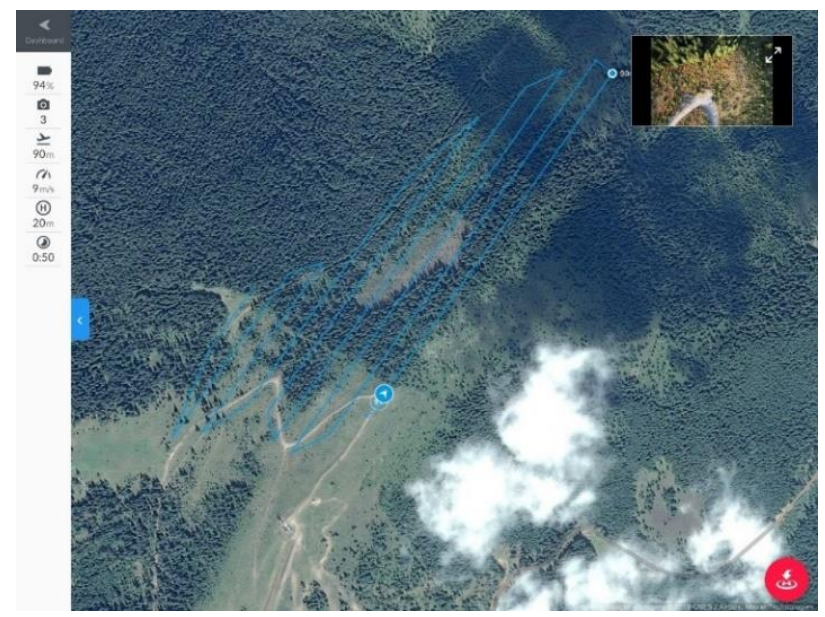

Figure 1. Performing the actual photogrammetric flight

In the raw image import stage, the 288 frames that were taken during the photogrammetric flight are entered in the program. At the same time, the projection system is chosen in which the data will be processed and the coordinates of the frames will be converted into the new projection system.

The collection of landmarks in order to align the frames is based on establishing the accuracy of identification and then how to select the pairs. In this case there are three options:

- $\quad$ Disabled - pairs are selected one by one;

- Generic - the selection of pairs is done on blocks in a block;

- $\quad$ Reference - the selection of pairs is made based on coordinates;

Then choose the maximum number of key pairs and connection points.

Aerotriangulation compensation is performed automatically by the software that has implemented the calculation principles presented below. The band block compensation has as compensation unit the general stereomodel of each of the bands. All bands form a block and are compensated simultaneously using grade II or III polynomials.

The coefficients of the polynomials are specific to each band $\mathrm{k}$ and are determined as a block based on relative or absolute discordances. The relative discrepancies are the differences between the coordinates of the connection points between two adjacent bands, and the absolute discordances are the differences between the field coordinates and the model, transformed coordinates of the support points.

Accuracy of aerotriangulation: at this stage the following aspects are pursued:

- $\quad$ metric and photographic frame quality (resolution);

- $\quad$ precision of marking and transposition of connection points;

- the precision of identifying the landmarks on the frames;

- number and arrangement of landmarks.

In the case of planimetric landmarks, it is recommended that they be arranged on the entire perimeter of the block to ensure high accuracy, regardless of the size and shape of the block. They must be placed at 5 bases on the parallel sides of the block and at 4 bases on the transverse sides.

It is necessary to have at least 3 altimetric landmarks on a strip, placed at the beginning, middle and end. Higher accuracy is obtained when there is a distance of 5 bases between the known elevation points. The altimetric landmarks are located at 5 bases on the parallel sides of the block and at 4 bases on the transverse sides. In practice, the planimetric and altimetric landmarks coincide.

The digital elevation model (DEM) is generated based on the dense point cloud (Figure 2).

Once the dense point cloud has been created, the desired projection system must be chosen and then the actual generation of the terrain model is performed.

The digital elevation model obtained has a resolution of $13.7 \mathrm{~cm} / \mathrm{pixel}$ and a point density of 53,22 points/sqm. Also, we can observe that the altitude of the studied land varies between $1530 \mathrm{~m}$ and $1690 \mathrm{~m}$.

In order to obtain the digital orthophotoplan, certain parameters must be selected, such as: resolution, the surface on which the orthophotoplan is modeled, projection system and color correction (if applicable).

Following the photogrammetric flight, a digital orthophotomap (Figure 3) was obtained with a resolution of 3.43 $\mathrm{cm} /$ pixel, equivalent to a scale of 1:343. This orthophotoplan will serve as a support for the preparation of the cadastral documentation of detachment from which will result two lots. Also, through this measurement, a check of the contour registered in the Land Book can be performed. 
Detachment is the cadastral operation by which a land area is divided into two or more lots. Following this detachment, two lots will result, one with an area of 210,353 sqm, and the second with 2,000 sqm. Both lots have access to the road.

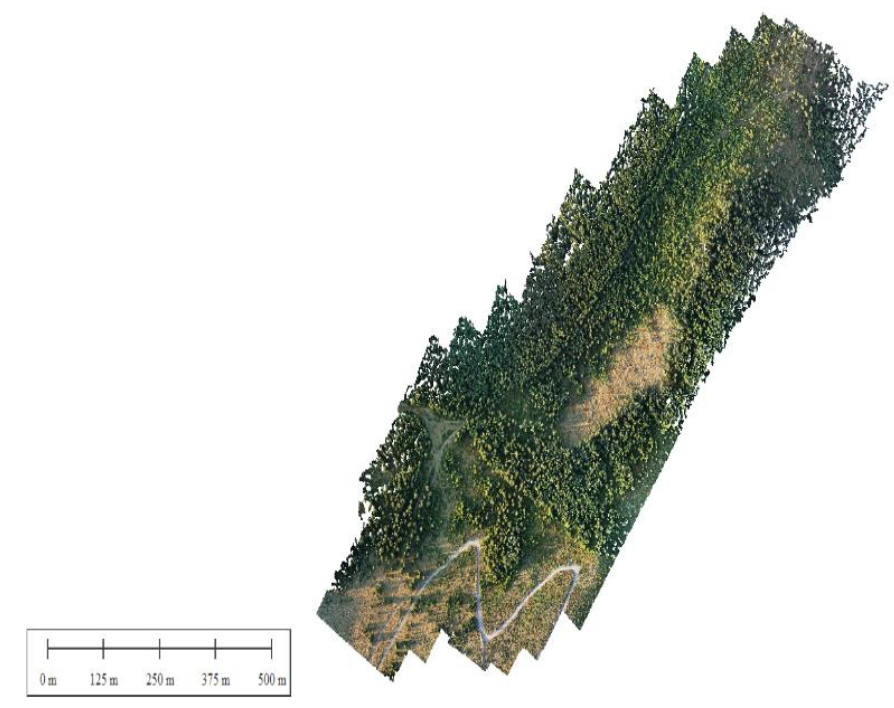

Figure 2. Dense Cloud Point

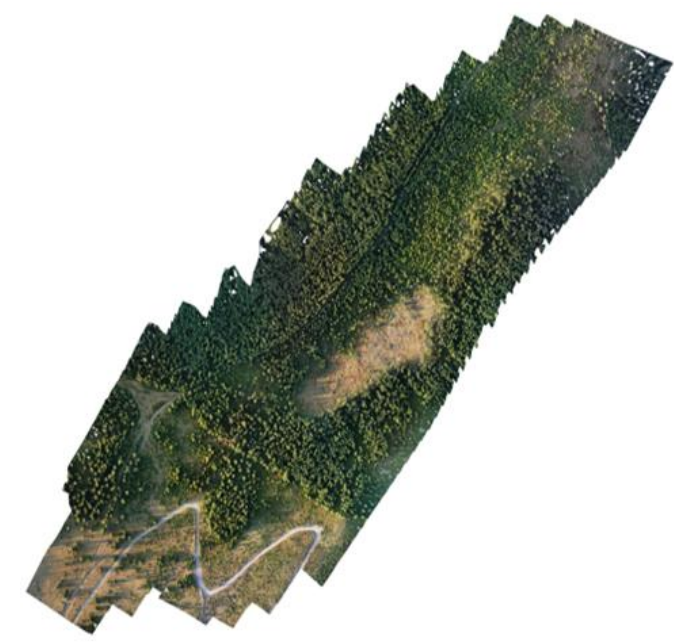

Figure 3. Ortophotomap

The cadastral documentation for detaching a building contains:

- payment proof of the tariff;

- the request for reception;

- the statement on one's own responsibility regarding the identification of the measured real estate;

- copies of identity documents, in the case of natural persons owners/certificate issued by the community public service by the population records from which to result the identification data or the ascertaining certificate, in the case of legal entities;

- copy of the land book extract for information or copy of the land book;

- the urbanism certificate, in the cases provided by law;

- the inventory of coordinates of the station points and of the radiated points;

- analytical calculation of surfaces;

- technical memory;

- copy of the plan that was the basis for registration in the land book of the building for which the update is requested;

- location and delimitation plan with detachment proposal;

- location and delimitation plans for each building resulting from detachment;

- .cpxml file.

\section{CONCLUSIONS}

Within this paper, the presentation of the works necessary for the elaboration of a cadastral documentation for detaching a building was made, when the UAV technology is used. This detachment resulted in two lots, one with an area of $208352 \mathrm{sqm}$ and the second with an area of $2000 \mathrm{sqm}$, and the smallest lot will be given for rent or concession.

The measurements were performed using a total Leica FlexLine TS03 station, two Trimble R8s GPS receivers and a DJI Phantom 4 Pro drone. Specific measurement methods were applied. The direct orientation method was used to determine the horizontal angles, the fast static and real-time kinematic GNSS methods were used and the UAV photogrammetric method was also used.

The verification of the support network was performed both from a planimetric point of view by the method of conditioned measurements and altimetrically by the trigonometric leveling at long distances. The network was thickened, being framed a new point, the compensation of the coordinates of this point was made by the method of indirect measurements.

Specialized programs such as DroneDeploy, Agisoft Photoscan, Global Mapper, AutoCad and Microsoft Excel and Word were used. 
The UAV photogrammetric technology was used for the purpose of preparing the cadastral documentation and for verifying the contour registered in the Land Book. By applying this technology a digital orthophotoplan was obtained.

Author Contributions: E.E.S., M.E.N. Conceived and designed the analysis; E.E.S.., J.D., S.C. Collected the data; I.L., D.F. Contributed data or analysis tools; I.C., E.E.S,., S.C. Performed the analysis; E.E.S,, M.E.N. Wrote the paper.

Funding Source: This research was elaborated from own resources.

\section{Acknowledgments}

This research did not receive any specific grant from funding agencies in the public, commercial, or not-for-profit sectors.

\section{Conflicts of Interest}

The authors declare that they do not have any conflict of interest.

\section{REFERENCES}

1. Bădescu G, Ștefan O, Pop N, Ortelecan M, Dirja M, Joldiș (Bădescu) R, Sălăgean T (2011). Ortophotomaps Use and System GNSS Position Determination Rompos Project Management Mine Closure in Maramureş County the Use of GIS, Agriculture-Science and Practice Journal. 79(3-4): 159-162.

2. Călin M, Damian G, Popescu T, Manea R, Erghelegiu B, Sălăgean T (2015). 3D Modeling for Digital Preservation of Romanian Heritage Monuments, Agriculture and Agricultural Science Procedia, 6: 421-428.

3. Carvajal F, Aguera F, Perez M (2011). Surveying a Landslide in a Road Embankment Using Unmanned Aerial Vehicle Photogrammetry. ISPRS, XXXVIII-1/C22: 201-206.

4. Coșarcă C (2003). Engineering Topography. Bucharest: Matrixrom.

5. Dragomir PI, Docan DC, Clinci TS (2015). Basics of engineering geodetic measurements. Bucharest: Conspress.

6. Ficior D, Sălăgean T, Ortelecan M, Pop N (2011). Study to Locate a Forest Shelter-Belt Network in Făget Area, Agriculture-Science and Practice Journal, 79(3-4): 155-158.

7. Herbei MV, Herbei R, Smuleac L, Sălăgean T (2016). Using Remote Sensing Techniques in Environmental Management, Bulletin UASVM series Agriculture 73(2): 230-237.

8. Ionescu I (2004). Engineering photogrammetry - Digital altimetric modeling of the terrain. Bucharest: Matrixrom.

9. Moscovici AM, Văduva R, Sălăgean T, Călin M, Păunescu V (2016). Mapping Brownfields as an Urban Planning Action, Agricultura - Ştiinţă şi Practică, 1-2(97-98): 156-159.

10. Neuner J (2000). Global positioning systems. Bucharest: Matrixrom.

11. Ortelecan M, Sălăgean T, Pop N, Ficior D, Deak J, Lupuț I (2016). Aspects Regarding the Establishment of the Scale Coefficient in the Case of Distances Measurements in a Geodetic Network, Bulletin UASVM Horticulture 73(2): 315-320.

12. Păunescu C, Dimitriu SG, Mocanu V (2012). Global Navigation Satellite System (GNSS). București: University Press.

13. Păunescu V, Călin M, Sălăgean T, Moscovici AM (2016). Analysis Regarding the Importance of GIS for Local Administration Process, Agricultura - Ştiință şi Practică. 1-2(97-98): 139-144.

14. Păunescu V, Călin M, Manea R, Moscovici A, Sălăgean T (2017). GIS in Active Monitoring of Green Spaces, Modern Technologies for the $3^{\text {rd }}$ Millenium: 73-78.

15. Popescu GS (2010). Photogrammetry for everyone to understand. Bucharest: Matrixrom.

16. Sălăgean T, Șuba EE, Deak J, Chiorean S, Pop ID, Matei F (2018). The Automatization of Forest Management Works in Romania using GIS and UAV Photogrammetry. Green Room Sessions 2018 International GEA (Geo Eco-Eco Agro) Conference - Book of Proceedings, Podgorica, Muntenegru, ISBN 978-9940-694-09-8: 240-253.

17. Sălăgean T, Șuba EE, Moscovici AM, Păunescu V, Călin M, Iliescu A, Pop ID (2019a). The Use of UAV in Urban Public Utility Systems. Modern Technologies for the 3rd Millenium, April 4-5, 2019, Oradea, Romania, ISBN 97888-87729-41-2: 67-72.

18. Sălăgean T, Șuba EE, Pop ID, Matei F, Deak J (2019b). Determining Stockpile Volumes Using Photogrammetric Methods. Scientific Papers. Series E. Land Reclamation, Earth Observation \& Surveying, Environmental Engineering. Vol. VIII: 114-119.

19. Sestraș P, Bondrea MV, Cetean H, Sălăgean T, Bilașco S, Naș S, Spalevic V, Fountas S, Cîmpeanu SM (2018). Ameliorative, Ecological and Landscape Roles of Faget Forest, Cluj-Napoca, Romania, and Possibilities of 
Avoiding Risks Based on GIS Landslide Susceptibility Map, Notulae Botanicae Horti Agrobotanici Cluj-Napoca, 46(1): 292-300.

20. Sestraş P, Sălăgean T, Bilașco S, Bondrea MV, Naș S, Fountas S, Cîmpeanu SM (2019). Prospect of a GIS Based Digitization and 3D Model for a Better Management and Land Use in a Specific Microareal for Crop Trees. Environmental Engineering and Management Journal, 18(6): 1269-1277.

21. Șuba EE, Sălăgean T, Pop I, Matei I, Deak J, Coroian I, Ficior D (2017a). Using Photogrammetric UAV Measurements as Support for Classical Topographical Measurements in Order to Obtain the Topographic Plan for Urban Areas, Bulletin UASVM Horticulture 74(2): 197-203.

22. Șuba EE, Sălăgean T, Onose D, Rusu T, Chiorean S, Matei F, Pop I (2017b). Creating a Mathematical Flood Area Model for Nistru River, Maramureş County. AgroLife Scientific Journal, 6(1): 249-256.

23. Șuba EE, Sălăgean T, Onose D, Pop ID, Matei F, Ortelecan M, Coroian I, Chiorean S (2019). Creating the Cartographic Database and Informatization of Systematic Cadastre Works Process. Bulletin UASVM Horticulture 76(1): 114-119.

24. Toderaș T (2007). Photogrammetry. Sibiu: Lucian Blaga Univ. Press.

25. Vorovencii I (2010). Photogrammetry. Bucharest: Matrixrom. 